\title{
UM JUIZ MAGISTRAL: \\ Comentário sobre a obra de Eliézer Rosa
}

\author{
Oscar Maciel Trindade Netto ${ }^{1}$
}

\section{RESUMO}

O artigo apresenta um perfil do grande juiz e jurista Eliézer Rosa, com base em suas obras e no exercício da judicatura, trazendo-o como exemplo de relações éticas e humanas para a magistratura brasileira.

Descritores: Eliézer Rosa: biografia. Magistratura: Brasil. Humanismo. Direito: ética. Filosofia do Direito. Direito processual civil.

Quand on veut que les rossignoles chantent bien, on leur crève les yeux. Quand Dieu veut avoir de grands poètes, il en choisit deux on trois auxsquels il envoie de grandes douleurs. (Daudet)

\section{INTRODUÇÃO}

Atendendo a honroso convite deste magnífico jurista, Dr. Marco Aurélio Costa Moreira de Oliveira, exemplo para a classe dos Advogados, instando-me a escrever sobre Eliézer Rosa, ouso entregar estas linhas, ao eminente Dr. Marco Aurélio, a quem, igualmente, presto minhas homenagens de admirador das peças forenses que tive oportunidade de ler, das brilhantes sustentações orais que testemunho quando compareço no Tribunal de Justiça do Estado e o encontro na luta diária da advocacia, bem como do magnífico livro Justiça e Ética: Ensaio sobre o Uso das Togas - verdadeiro e belíssimo

1 Advogado (OAB/RS 7281), membro do Instituto dos Advogados do Rio Grande do Sul desde 1974, Pós-Graduação, Latosensu: Especialização em Processo Civil pela Universidade Federal do Rio Grande do Sul (UFRGS). Endereço profissional: Largo Visconde do Cairú, 12, cj. 102, Centro, Porto Alegre, RS, Brasil, 90.030-110. Endereço eletrônico: trindade@trindade.adv.br. 
guia para os advogados, além de festejado Professor de Direito de inúmeras gerações de jovens que até hoje buscam no conhecimento e saber sob a orientação do Mestre, os meios de ascenderem profissionalmente, confortados pela reconhecida cultura jurídica e lucidez de um jurista de escol.

Escrever sobre Eliézer Rosa não é tarefa fácil, ao contrário, no mínimo delicada, em razão da sua grandeza humana e profissional.

\section{ELIÉZER ROSA}

A obra escrita e o exercício da atividade profissional como Juiz de Direito sempre estiveram repletas do mais profundo humanismo. Foi um dos pioneiros nos estudos do Processo Civil no Direito Brasileiro em termos de construção jurídico-científica; aluno do grande Liebman; Juiz de Direito Criminal da $8^{\mathrm{a}}$ Vara Criminal do Rio de Janeiro; alma de poeta, coração de poeta; grandioso escritor de fina, suave, bela e fidalga maneira de escrever, levando-nos ao encantamento pelo português escorreito, mais parecendo a construção de uma catedral gótica, em que a imagem do homem ocupa papel predominante. Foi um apóstolo de bondade, um humanista. Couture era-lhe o poema diário. Liebman era-lhe a lição grave, a ciência austera, o induvidoso magistério. Carnelutti e Chiovenda foram seus grandes inspiradores em matéria processual civil e penal. Leitor dos clássicos italianos, portugueses, franceses, ingleses e brasileiros; possuidor de uma vasta e incomparável cultura clássico-humanista.

Viveu com a familia, unido à esposa por mútuo e recíproco sentimento de profundo amor, circunstância que todos observavam com profundo respeito. O casal teve uma filha, que por sua vez lhes deu um neto. Residiu grande parte de sua vida no bairro de Laranjeiras, Rio de Janeiro, na Rua São Salvador.

O domicílio em que, igualmente, amou e sofreu, foi o Foro Criminal: vendo, ouvindo, sentindo e julgando a criatura humana, com a mais formosa das sensibilidades que consiste na caridade, na piedade e na compaixão pelo ser humano que tinha de julgar, vivendo a mais dolorosa de todas as batalhas, a luta dos seus sentimentos e a obrigação de aplicar a lei, muitas vezes, fria, rígida e impessoal, obrigando-o ao ato judicial de condenação, que para ele constituía na dolorosa miséria do processo humano, porque ela, sentença condenatória, dizia, não poderá nunca ser obra do sentimento do Juiz.

Ao referir-se ao acusado, disse Eliézer Rosa, com a sensibilidade especial que possuía: 
Os que lidam no mundo enfermo da Justiça Penal hão de ter sempre presente em seu espírito que estão tratando com pessoas feridas pela vida, pelas brutalidades do cotidiano. Há que escolher palavras; há que tratar com maior cuidado, porque um olhar mais duro, uma voz mais carregada, tudo são dissonâncias para a alma sensível e doente do que está diante da pessoa do Juiz. Todo réu é um humilhado e um ofendido pela própria vida. O tratamento cordial dispensado aos réus é um dever de todos que lavramos a terra escaldante, o chão de espinhos duma sala de audiências criminais (Rosa, 1975b, p. 55).

Foi um incompreendido por alguns, no Foro, admirado pela maioria, e respeitado por todos que testemunharam a verticalidade da sua conduta pessoal e profissional; varão ilustre, que teve a lhe acompanhar penosamente, dentro da própria família, a aflição e o inaudito sofrimento da doença nos seus afetos, enfermidades que por vezes vergastam nossos entes queridos, ferindo a alma e queimando o coração, ao longo do enigma da vida, que só Deus poderá nos elucidar.

Eliézer Rosa foi o Magistrado que proferiu as primeiras sentenças de prestação de serviços à comunidade, sempre carregadas de um profundo caráter pedagógico. E.g., como a do motorista que atropelou um pedestre, condenado a, diariamente, comparecer em um Hospital de acidentados no trânsito, Hospital Souza Aguiar no Rio de Janeiro, e auxiliar no atendimento aos acidentados, e, assim, pela simples visão das pessoas feridas e/ou mortas, o motorista um dia entre lágrimas foi ao gabinete do Juiz Eliézer Rosa e lhe disse: "que aquela condenação estava sendo a mais prática e convincente lição que recebera e que doravante iria dirigir com redobrada cautela"; outro caso interessante trata de dois sambistas do morro - um compositor e um passista - que se engalfinharam numa briga de rua com lesões corporais; o compositor declarado culpado foi condenado a compor um samba ao passista, circunstância que aproximou os desavindos e até os dias de hoje são sinceros amigos.

Era comum o grande Juiz Eliézer Rosa, acompanhado de motorista, subir o morro levando alimentos à família de alguém que se obrigara a condenar, em absoluto sigilo, e sem nenhum alarde, de forma totalmente incógnita, pois. confessava aos amigos, a família não tem culpa pelo erro do seu chefe. Sentenças que pelo seu ineditismo, à época, causaram perplexidade em muitos juristas, e, eram, reiteradamente, reformadas no Tribunal, vindo muitos anos após, esta ideia de punição/pedagógica e educativa, a fazer parte do arsenal de soluções do sistema penal brasileiro.

Assim, por mais que escrevêssemos e enumerássemos, diríamos pouco sobre este notável Juiz brasileiro, que ensinou-nos da nobreza e 
da grandeza do ato de julgar, além de ter falado e muito bem do advogado, mercê da convivência diária no Foro com os advogados a quem conheceu de muito perto.

Certa ocasião, falou:

Disse o imortal Rui, sem Deus não há justiça. Digo eu, o mais humilde dos Juízes; Apenas menor que os anjos foram feitos os advogados, pois sem eles, as salas de audiências se converteriam em impérios do arbítrio e reinos do despotismo, onde se instalaria a mais danosa de todas as ditaduras, a ditadura do Judiciário. (Rosa)

Temos uma imensa dívida de gratidão, nós Advogados, com Eliézer Rosa, que de forma significativa enobreceu, honrou, dignificou e engalanou a Magistratura deste País, desde antes da metade do século passado e ao longo dos anos que se seguiram até o seu jubilamento, com rápidas passagens como Juiz Substituto do então Tribunal de Alçada da Guanabara. Dívida que não pagaremos jamais, tal a grandeza da obra magnífica por ele legada nos livros de Processo Civil e Processo Penal, arrolamos alguns; ${ }^{2}$ ao lado das lições de vida proferidas nas salas de audiências, consubstanciados nos despachos e sentenças que, por seu conteúdo humano e jurídico de inigualável beleza ética e estética, nos reconciliam com a certeza esquecida e, lamentavelmente, olvidada, por tantos doutos de que o direito está posto para a criatura humana e não o contrário, como Eliézer, incansavelmente, repetia.

Lapidar, extraordinário, inigualável a beleza moral, ao dizer sobre a sentença, passagem magnífica, servindo de ensinamento a todos, especialmente, àqueles que trazem a missão humana de julgadores:

Hoje, pobres de nós, operários de uma técnica sem alma e sem piedade, enfeitiçados por ela, dela amorosos até o feiticismo, somos dela levados, e consumamos sua obra, indiferentes aos resultados, preocupados apenas em que eles sejam tecnicamente incensuráveis.Éaperfeição formalque nos encanta. Somos enamorados da forma, artistas plásticos, trabalhando sobre dores humanas, mas a elas indiferentes. E ainda mantemos sobre nossa mesa a monstruosa imagem da Justiça de olhos vendados (Rosa, 1975b, p. 225).

2 Capítulos de história do direito processual civil brasileiro. Rio de Janeiro: Rio, 1975. 3 v. (Cadernos de processo civil, 3).

Dicionário de processo penal. Rio de Janeiro: Rio, 1975. 267 p.

Dicionário de processo civil. 2. ed. São Paulo: José Bushatsky, 1973. 427 p.

Novo dicionário de processo civil. Rio de Janeiro: Livraria Freitas Bastos, 1986. 322 p. A voz da toga. 3. ed. Goiânia: AB, 1999. 120 p. 
Trago, neste modesto e despretensioso artigo, pálido reflexo da beleza imorredoura legada por Eliézer Rosa em seus escritos. Limitado demais para conter e contar as passagens de notável humanismo que nos deixou, em espólio imaterial de valor incalculável que nós devemos passar às gerações vindouras em verdadeiro fideicomisso compulsório, na sequência interminável das gerações que à Casa da Justiça virão, hoje e sempre.

Impossível alinhar toda a beleza e magnitude do que escreveu Eliézer

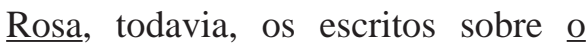

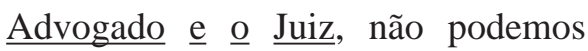
nos furtar de trazê-los às gerações dos jovens que, diariamente, vão e irão à Casa da Justiça, e haverão de compreender a imensa e luminosa beleza ética dessa profissão, que tem qualquer coisa de sagrada.

Meditei longamente em escrever sobre o grande Juiz, e creio despossuído de dizer mais e melhor, entendi que só a transcrição da integralidade de alguns textos, quase todos em obras esgotadas, verdadeiras relíquias, mostrará às gerações de hoje e às vindouras o gênio da sensibilidade no ato de julgar, na arte de escrever, no humanista que ocupou o cargo de Juiz Criminal Brasileiro, exemplo para a sua Classe, exemplo para todos nós, verdadeiro desbravador da alma humana nos tribunais, olhando para a criatura não com a severidade dos infalíveis, mas com a compreensão das misérias que a todos nós aproxima e irmana, com a superior beleza ética do homem sensível, a quem a dor alheia lhe causava sofrimento que o seu semblante e a sua voz facilmente se mostrava e identificava ao interlocutor que o via e ouvia.

Eliézer Rosa escreveu sobre o advogado texto magnífico, que retrata a luta e a saga dessa profissão, que, quase sempre, se converte num altar onde o advogado comunga com seu constituinte a penosa eucaristia da dor. Ei-las.

Advogado. É o bacharel ou doutor em Direito inscrito no quadro dos advogados da Ordem dos Advogados do Brasil. Há de entender-se que advogado é o que advoga, ou tomando as próprias palavras da lei: é aquele que, no seu ministério privado, presta serviço público, constituindo com os juízes e Membros do Ministério Público, elemento indispensável à administração da Justiça. Na fria singeleza de seu enunciado técnico, estas palavras do Estatuto da Ordem são como um verso de um imenso e belo poema que os homens vêm escrevendo, entre vigílias e sofrimentos, mas também entre alegrias e triunfos. A História da Liberdade dos homens reserva à Advocacia um vasto e glorioso espaço onde se inscrevem as lutas incruentas dessa milícia generosa e desarmada. Tem o advogado seu Código de direitos e deveres, onde está escrito o mínimo do que deve fazer; porque o máximo dessa sublime profissão 
já vem impresso na alma de cada um que a ela se dá na irresistível vocação para a memorável obra da Justiça. O mínimo do que deve fazer está na irredutibilidade moral de seus princípios e nas regras escritas a que deve o culto de sua fidelidade. O máximo dessa esplêndida profissão não está nem nunca poderia estar escrito, porque ele reside naindomável força de sua vontade, na confiança do seu saber, no arremesso glorioso de certos momentos transcendentes da vida profissional, que tudo exige do advogado, até por vezes a temeridade de um milagre. A boca sempre limpa nas palavras e nobre nas ideias, justa nos julgamentos e calma nas controvérsias, pura na contextura da frase e clara na nitidez da dicção, alta na voz e decisiva na sinceridade. Com estas palavras traçou meu inesquecido Mestre Daltro Santos, o perfil do Professor. Tomo-lhe de mútuo do retrato que de si mesmo fez o velho preceptor, para dizer-vos que isto deve ser o Advogado. Se tivesse de hierarquizar, pela superior beleza moral, as diversas profissões humanas, somente duas poria acima do advogado: o sacerdócio religioso e o magistério primário. É que em todas as tarefas humanas há o seu tanto de efêmero e transitório, de circunstancial e puramente temporal. Só o Padre ou Pastor trabalham para a eternidade, encaminhando as criaturas a Deus. Só o instituidor primário constrói, forma e informa homens para a Humanidade. O Advogado, mesmo servindo aos homens, edifica e embeleza a obra da Justiça, continuando a obra da Justiça da criação do mundo, como se Deus houvesse encarregado a esses operários por Ele eleitos a tarefa do oitavo dia da criação do mundo. Sem a Justiça a obra divina da criação estaria incompleta. Deus parou no sexto dia. Descansou no sétimo, mas sentiu que só no oitavo dia poderia ser completada a obra da gênese com a instituição da Justiça. E foi então que criou o Advogado e entregou-lhe a missão da Justiça. Sois os operários chamados por Deus para esse amável serviço do oitavo dia da criação. Advogado e advocacia são termos análogos. Ela é o ministério privado do advogado. E a advocacia como a sinto e amo, é substancialmente paixão da verdade, amor do bem, culto da honra, combate pelo Direito, sacrifício pela Justiça. É simpatia na dor, é aliança no sofrimento, é caridade evangélica para com o próximo. É desinteresse, é renúncia, é concordância, são vigílias, são fadigas, são martírios da alma e torturas da mente. É uma profissão humana, onde há qualquer coisa de sagrado. No Foro, ela é combate; no escritório, é pré-julgamento e conselho; no lar é estudo, meditação e planejamento, na comunhão dos livros. O conteúdo publicístico do moderno processo judicial aproxima Juízes e Advogados, fraternizaos, porque entre ambos não há nem hierarquia nem subordinação, devendo presidir nas suas relações um predominante e bilateral sentido de cordialidade, consideração e respeito, como, com gentil enunciado, está dito na lei, verificando um familiar costume que a todos os homens do Foro nos enlaça e nos une. Só uma fronteira existe e existirá para sempre entre ambas as classes: fronteira intransponível, que linda e demarca o lugar de cada um, em silêncio, como na 
paz dos jardins desabotoam as rosas. Essa linha lindeira e intransponível pelas sugestões da Ética, é o respeito humano e profissional lado a lado (Rosa, 1986, p. 42-46).

\section{Sobre o Juiz, disse Eliézer:}

Juiz. Aquele que julga no que diz respeito ao caso concreto a ele submetido por homens em conflito. Órgão, voz do Estado, na distribuição da Justiça. Membro do Poder Judiciário, detentor da função jurisdicional, cujo desenvolvimento é minuciosamente regulado pelo direito processual. O processo é a regulamentação do exercício da função jurisdicional. No processo está a disciplina da sua atividade que é destinada a atuar nas relações já reguladas pelo direito substancial. O juiz formula e torna efetivas as regras jurídicas concretas que governam as relações entre os sujeitos. O papel do juiz não é transformar a regra abstrata em regra concreta, porque juridicamente tal transformação já está operada, no momento em que o juiz julga, cabendo-lhe apenas constatá-la e declará-la. Logo que ocorrem os fatos juridicamente relevantes, já estão eles governados pela lei, e o processo lógico de concretamento da regra abstrata sobrevém automaticamente. É certo também que, em determinados casos, há efeitos que se produzem por obra propriamente da sentença. No maior número de casos, a regra concreta deriva logicamente da regra legal abstrata, mas não faltam casos excepcionais em que o juiz deverá procurar a regra abstrata em outros elementos, deduzindo-a livremente das convicções jurídicas difusas no povo, tendo em conta o tempo e o lugar em que exercita seu ofício, como por exemplo, nos casos em que decide por equidade. Seria, porém, vã e incompleta a obra do juiz se ele se limitasse a exprimir um juízo sobre o caso a ele trazido para exame. O juiz deve conduzir a efeito, no mundo da realidade prática, o conteúdo da regra jurídica concreta, de modo que a situação de fato venha a coincidir com aquilo que a regra jurídica concreta estabelecer. Para que a justiça se torne realidade viva e operante é necessário que ela se traduza em fatos reais. Daí se chamar a uma atividade cognição e à outra execução. Além dessas duas atividades, está posta uma terceira, de caráter complementar, que se desenvolve no processo cautelar. Seu escopo é o de evitar que, durante o tempo necessário ao desenvolvimento do processo, circunstâncias particulares, que se temem, venham alterar a situação das coisas de modo a tornar praticamente ineficaz a tutela pretendida. Tem-se, então, que o juiz julga, executa e acautela. O poder de que está investido o juiz lhe é conferido diretamente pela lei constitucional. É, porém, um poder genérico abstrato, meramente potencial, que poderá tornar-se efetivo e exercitar-se em concreto se diante dele se propõe uma demanda judicial. Só neste caso, surgirá a relação processual, isto é, para o juiz, o poder de exercitar em concreto a jurisdição. E é porque a relação processual nasce da propositura da ação, dando ao juiz o poder de exercitar em concreto seu poder jurisdicional, que o juiz 
não pode julgar fora dos limites do pedido. Tem-se trazido em questão, em largas disputações doutrinais, qual a natureza jurídica do processo: se é relação processual ou se é situação processual; se é instituição ou contrato. Fico na autorizada lição de Liebman, a quem sempre sigo e por vezes transcrevo e copio. O que envolve juiz e partes é uma relação processual, relação jurídica particular, que só existe, porque uma demanda foi proposta, e que cria entre juiz e partes vínculos juridicamente relevantes e juridicamente regulados. É uma relação una, mas uma unidade complexa, que perdura e progride do primeiro ao último ato do processo. No centro dessa relação se encontra o juiz, com seu poder jurisdicional e, em volta dele, as partes, e suas posições subjetivas e sujeições. E por isso que o processo é uma relação jurídica, a posição das partes não é a de sofrer passivamente a atividade do órgão jurisdicional. Têm elas o poder de iniciativa, que depende em grande parte a marcha do processo e sua direção. Se é exato que a atividade do juiz produz situações jurídicas passivas, que consistem no estado de sujeição das partes aos efeitos da dita atividade, étambém certo que as partes sempre podem fazer alguma coisa para evitar o dano que tal sujeição poderia advir, exercitando os ônus que lhes competem, e outras vezes, se bem que em menor proporção, os direitos subjetivos que lhes cabem. Do ponto de vista do Processo, é o juiz um terceiro não interessado no conflito que é chamado a julgar. $\mathrm{O}$ juiz julga e provê sempre condutas de outrem, em caráter substitutivo, isto é, o juiz faz o que o interessado no conflito não fez. $\mathrm{O}$ vencedor obtém por obra do juiz aquilo que não conseguiu obter voluntariamente do vencido, antes de trazê-lo a juízo. Por isso se diz que a função jurisdicional tem caráter substitutivo, secundário ou instrumental. O juiz é sempre uma figura do seu tempo e do seu meio porque ele será sempre aquilo que for a jurisdição. A função jurisdicional modela o juiz, cria-o à sua imagem e semelhança. $O$ que o Estado quiser que seja o juiz, a direção política, sociológica, filosófica de seus julgamentos, o Estado obtém, preenchendo o conceito de jurisdição com as ideias do seu agrado e conveniência. E o juiz é o servo da jurisdição. $\mathrm{O}$ juiz pode fazer quase tudo. E só não faz tudo, exatamente tudo, porque ele não poderá nunca mudar na jurisdição a marca que, de suas ideias, nela imprimiu o Estado. A moderna Filosofia do Direito está procurando recortar uma nova figura de juiz. No dia em que o juiz for aquilo que a nova concepção da função jurisdicional quer que ele seja nesse dia, o juiz, por obra da Justiça, criará um novo mundo. $\mathrm{O}$ velho testamento jurisdicional e seus profetas passarão com a velha ordem e a velha dispensação. Um novo e esplêndido dia virá para os homens que têm fome e sede de Justiça, e eles serão bem-aventurados e satisfeitos. Um novo Sermão da Montanha se está preparado para a Filosofia do Direito. E nele se pregará:

Bem aventurado o juiz que já não tem a concepção mecânica da jurisprudência. Bem aventurado o juiz que já não tem carência de 
sinderese para a obra da Justiça. Bem-aventurado o juiz que já não se interessa pelo racional, mas quer nas suas decisões o razoável. Bem-aventurado o juiz que tiver seu pensamento guiado pela lógica do humano e já tiver ultrapassado a lógica de tipo matemático nos julgamentos do homem e para o homem. Bem-aventurado o juiz que se deixar governar na interpretação jurídica pelo"logos do humano, abandonando a razão matemática na interpretação dos conteúdos jurídicos. Bem-aventurado o povo que tiver juízes assim. Bem-aventurado o homem que for julgado por juízes assim. Bendita será nesse dia a obra da Justiça, porque não haverá choro nem ranger de dentes, quando soarem as derradeiras palavras de sentença do juiz. Quando esse dia vier, o juiz estará definitivamente convencido de que o direito foi feito para o homem e seus problemas (Rosa, 1986, p. 42-46).

Cabe transladar aqui um formoso trecho de Recaséns:

[...] o processo de interpretação de uma norma geral a propósito dos casos singulares, a individualização das consequências de tal norma para tais casos, e as variações que a interpretação e a individualização devam ir experimentando, tudo isso deve cair debaixo do domínio do logos do humano, do logos da ação humana. Não é algo fortuito, nem tampouco algo que possa ser decidido arbitrariamente, e sim resolvido razoavelmente. Para isso, porém, não servem as razões do tipo matemático. A lógica tradicional, a lógica da razão pura, não serve para tratar nem resolver tais problemas. Temos necessidade de outro tipo de lógica, mas diferente da lógica tradicional: o de que precisamos é da lógica do humano, a lógica do razoável, que é diferente da lógica do racional. [E mais este trecho:] ... a lógica tradicional é meramente enunciativa do ser e não do não-ser, porém não traz pontos de vista de valor nem de estimações sobre a correção dos fins, nem sobre a congruência entre meios e fins, nem sobre a eficácia dos meios em relação com determinado fim (Recaséns Siches, 1956, p. 140, tradução livre).

O Juiz do nosso tempo e para o nosso tempo é aquele que deixar de lado a lógica de tipo matemático, que abandonar o racional e buscar o razoável, entendendo por razoável aquilo que melhor convier ao homem julgado, que lhe infligir menor sofrimento. É mais fácil julgar, fazendo da sentença um silogismo, em que a lei é a premissa maior, o fato, a menor e o dispositivo da sentença, a conclusão. Não importa para tal Juiz se a conclusão traz ou não maior sofrimento ao homem, porque o Juiz se sente pago da observância formal das regras do silogismo. Sua consciência descansa tranquila, porque ela lhe atesta a obediência do formalismo do pensamento lógico. Isso é mais simples e mais fácil. E até uma máquina poderia fazer. A esta concepção da tarefa jurisdicional se chamou concepção mecânica da jurisdição. Mas, evidentemente não é assim o Juiz do nosso tempo e para o nosso tempo. Ele tem de saber que está julgando homens e suas 
circunstâncias, está julgando homens cuja vida não segue a normalidade estática de um silogismo. É um ser vivo que muda a cada instante, segundo as circunstâncias que o rodeiam. Fui educado numa religião que ensina o respeito ao livre arbítrio do homem, que ensina que o homem foi criado livre e responsável pelos seus atos. Por isso conservo a concepção do homem como ser livre de pensar e querer. Sua grandeza está na sua responsabilidade, na responsabilidade que decorre dos atos que pratica livremente. Mas, ao compasso da vida e da minha experiência de juiz criminal, vendo o contraponto terrível da existência, fico a meditar sobre se tal concepção vale também para o Direito. Deverá valer, para não minimizar o homem, mas o juiz terá de temperar tal concepção com o conhecimento que ele tem do homem, com o conhecimento que tem das limitações do homem que ele vê e que julga, e que é um ser semelhante. Muitas vezes praticamos um vitando bovarismo, castigando, nos outros, aquilo que nós seríamos também capazes de fazer. Como disse o velho pensador: Homem sou e nada do que é humano reputo alheio a mim. Daí a necessidade de o Juiz do nosso tempo e para o nosso tempo saber que deve praticar o razoável e não o puramente racional. É o logos do humano, o sentido humano das condutas o que deve ser procurado e achado pelo Juiz para que sua sentença seja uma catarse, para que ela purifique o homem. $\mathrm{O}$ réu tem necessidade da sentença que o condene, por ela, ele sente que está quitado com a sociedade. Já tereis se surpreendido, na tosca linguagem dos réus, essa rica declaração, rica de sentido existencial: já paguei o que devia. O já paguei tem uma carga de verdade psicológica que a muitos tem passado despercebida. Quando uma dívida nos oprime e conseguimos pagá-la, sentimos um alívio, como se tivéssemos retirado um peso de sobre nós. É esta sensação que sente o delinquente quando é condenado e cumpre sua pena. Esse valor espiritual da sentença. Mas, para que o réu sinta esse alívio, necessário se faz que a sentença não lhe acarrete uma sobrecarga. O réu deve sentir que pagou exatamente o seu débito e não mais. Não há juros nas dívidas para com a lei. Mas há sentenças que estão contando juros com correção monetária. Certa feita, uma mulher aflita me telefonou pedindo inutilmente que a auxiliasse, pois seu marido havia sido condenado a um ano de prisão pela emissão de um cheque sem provisão bancária. E o valor do cheque era de Cr\$ 17,00 (dezessete contos em linguagem mais impressiva). Em casos como esse eu pago o valor do cheque para não ter que condenar. Que os leitores desculpem a declaração. Evidentemente que condenar um homem a um ano de prisão por um cheque sem fundos de 17 contos não é praticar o logos do humano, mas o ethos da lei que nem sempre é o direito. Está certo o juiz, mas de um ponto de vista puramente formal. Mas, não é isso que se pede ao Juiz para o nosso tempo. Se o logos do humano, se o verbo humano lhe tivesse falado mais alto que a linguagem fria do ethos da lei, sua sentença seria mais humana e mais jurídica, embora menos legal. Não é o legal que importa, mas o jurídico. Não estou a dizer que 
o Juiz desrespeite o direito positivo. Um de nossos deveres primários é a obediência ao direito posto pelo Estado. Mas, há uma rica e divina maneira de obedecer ao direito positivo sem desobedecer o razoável. É o que se consegue através da interpretação da lei. Aqui se esconde o difícil, mas o substancial de nossa amarga tarefa de julgadores de homens. Há que ser o Juiz um criador, artista rico de poder criador. Nossa tarefa não tem semelhança talvez com nenhuma outra praticada por homens. Mas, bem procurada, é possível que se ache alguma paralela: é o músico de Jazz. Nós executamos em nosso ainda rude instrumento uma partitura, em que entra a inspiração de cada executante, dando lugar a muita improvisão no sentido de nada pensado, de produto de falta de reflexão. Improvisação no sentido de criar, de embelezar, de enriquecer, de pôr alma e sentimento naquilo que se está fazendo. Os juízes somos jardineiros de homens. Desçamos, pois, a cultivar nosso jardim de tormentas. Deus há de compensar-nos, embora os homens não nos compreendam. A nossa é uma tarefa de "apesar". Apesar de réu, ele, o julgado por nós, é um homem. E de "apesar" em "apesar", vamos tecendo nossa peça de arte, nosso mosaico de "apesares". Realizar o direito "apesar da lei". Este testemunho da nossa consciência é o que importa, apesar de tudo. Executemos nosso Jazz e cultivemos nosso jardim (Rosa, 1973, p. 262).

Qual o momento de maior expectativa, angústia, ansiedade, inquietude e sofrimento porque passa o advogado em sua vida profissional?
Creio, sinceramente, seja no momento da sentença, a decisão do processo em que se decidem os valores exponenciais da criatura humana que vem a nós em busca de socorro ao direito que postula, que (lhe $e$ nos) parece possuir; pois Eliézer Rosa, escreveu sobre a sentença de uma maneira arrebatadora, que nos faz sentir que ao escrever não era o cérebro privilegiado que ditava, nem o conhecimento haurido no exercício da Magistratura, mas a sensibilidade do coração e da alma desse eminente jurista que guiava a sua pena inigualável, como que a nos reconfortar com o gênero humano que produz um jurista da magnitude de Eliézer Rosa, ciente e consciente, que nada do que existe em nossa volta, produzido pelo homem nos oceanos de livros e palavras escritas e ditas nos Foros e Tribunais serve, se não estiver voltado para a criatura humana, finalidade maior do Direito na busca da Justiça, mesmo sabendo-se feita por homens falíveis com deficiências próprias da nossa condição humana.

Sentença, Generalidades sobre a. É a sentença formalmente o termo final do processo. Com ela, põe o Juiz fim no seu velho trabalho visível. Saem às partes, saem os advogados; mas, na arena quase vazia e silenciosa, permanecem sombras e lembranças da agitação das lutas que precederam a sentença. Lá, concentrado em si mesmo, fica o juiz a meditar na sua obra sempre inacabada. Ninguém 
pense que, proferida a sentença, ocorra aquilo de Pitigrilli, de o juiz, esfregando as mãos, dizer: acabei de fazer justiça, e sair, descansado e tranquilo. O drama prossegue em sua alma, por que, em verdade, prossegue também na dos litigantes. Nenhuma sentença é realmente definitiva. Toda sentença é um doloroso interlocutório entre desperos humanos. A coisa julgada é mais terrivel criação da ciência jurídica, porque ela fecha a boca ao que ainda tinha o que dizer, e já não pode mais. A sentença acaba apenas o processo, mas não acaba os ressentimentos, nem aplaca os ódios que os litigantes trouxeram em si em consigo. Só há uma sentença consoladora e, pois, definitiva, moralmente defitiva: é a sentença homologatória, aquela em que o juiz sela o acordo voluntário das partes. Enquanto for a sentença ato de vontade e da inteligência do juiz, haverá um remanescente de angústia, que só o tempo consome, diante do irreparável. A oralidade que pareceu a fórmula mágica da justiça, porque, como disse Couture, os homens entendemse falando, traz a marca originária de sua debilidade, exatamente porque se apoia na palavra. Esta, segundo a lição de um caricatural diplomata, foi dada ao homem para esconder seu pensamento. Nenhuma prova é isenta de erros. E quando Pitigrili disse que uma prova documental só é boa quando tem a confirmá-la uma boa prova documental, disse verdade, porque nem uma nem outra já merecem inteira fé. Já não se pode crer nem mesmo nos documentos, tal o poder satânico da obra mistificadora de falsificação. Quando o litigante era um crente. E o processo estava lastreando fé e virtude, presente nos juramentos, a sentença poderia ser tarefa consoladora.O laicismo invadiu o templo; os ateus tomaram os lugares dos fiéis, o compromisso substituiu o juramento, e lei do amor cedeu o lugar à lei escrita posta pelo Estado. Ela opera às vezes de fora para dentro, porque, no mais das vezes, nem isso acontece.

Na alta prosápia de sua originária semântica, sentencear e sentir era uma só e mesma coisa. Que sente o juiz ao pronunciar sua sentença? Sente o agulhão da responsabilidade profissional, que lhe fixa um prazo para proferi-la. Ele não sente, não pode sentir o que há de trágico e humano nas dobras do processo. Ele não vê, nem pode ver o tenebroso drama que se esconde nas folhas dos autos. Ele vê tudo através da técnica, das formas. Tudo sombras, e, às vezes, sombras de sombras, como desalentadamente o disse o egrégio Couture. Não é só porque o juiz moderno é um primoroso técnico, que ele vê tudo sobre o frio aspecto técnico. É porque o processo é isso sim, um instrumento técnico, uma esquisita máquina que opera quase por si só. Nem o juiz, as partes fazem o processo de ordenamento legal, cronometrando-o, minando-o de preclusões, e concebendo-o como um conjunto de situações em que a sujeição, tanto do juiz como das partes, é uma constante constrangedora e mortificante. É certo que há ônus; que sempre poderão as partes fazer alguma coisa para se libertarem de tal sujeição jurisdicional. O que podem, porém, é 
muito pouco, em face do que devem. Mas, há ainda uma nota trágica que colore o processo de angústia: é o tempo e a mole de seviços que os juízes temos de enfrentar sozinhos, já que a nossa tarefa é pessoal, ou antes, personalíssima. Ninguém pode fazer por nós, aquilo que só nós, podendo, ou não, temos de fazer, apesar de tudo. Um juiz pode tudo para os outros, disse o filósofo, mas não pode nada para si mesmo. Somos eternos Sísifos, subindo, sozinhos, com a pedra imensa de nosso cargo, a montanha que nunca se alcança. É assim que a sentença é também produto do cansaço, de exaustão física do fazedor de decisões. Oralidade, fórmula mágica da justiça, pensaram os homens de gabinete. E criaram a identidade física obrigatória, para que o juiz entrasse no processo junto e saísse junto com os litigantes. Oralidade, princípio mágico da justiça. E criaram a concentração, para que o juiz conservasse viva em sua lembrança o espetáculo da instrução, e nada se perdesse nos desvãos da precária memória humana, quando tomasse dos autos para dar sua sentença. Por sem dúvida que é a oralidade a mais famosa fábrica do pensamento processual do nosso tempo. Nela e por ela, quando tudo consente, pode o juiz sentir o processo, e, sentindo-o, pode, sentir todo o extenso que reside no processo, e, então, poderá sentir a sentença. Assim, poderá ser a sentença produto da inteligência, da vontade e do sentimento do juiz. A grandeza fria e solene do processo reside na porção declaratória que toda sentença traz em si. É produto puro de lógica, artefato acabado da inteligência do juiz. A dolororosa miséria do processo está na sentença condenatória, porque ela não pode ser obra do sentimento do juiz. Nunca, ou quase nunca poderia ser uma sentença condenatória criação impessoal das regras dum formal silogismo: lei-fatos-sentença. Não poderá nunca o juiz dizer, com essa liberdade, que só o artista tem consigo: segundo o que os autos mostram, a conclusão é essa; mas, segundo sinto, a conclusão é outra. A realidade não é a dos autos: é o que sinto humanamente, pelo que vi no rosto desta ou daquela parte, segundo entendi da expressão, da voz, e do tremor da inocência que senti, vendo e ouvindo o dolorosa acento da palavra do homem”. Toda a tragédia do juiz está nos fatos trazidos aos autos mediante alegações e provas. Mas, quem poderá afirmar que os fatos são tais quais foram postos diante do juiz? O contraditório é garantia, porque é liberdade de discução, de debates. É a impostergável necessidade de ser ouvida a parte contrária. Mas, onde andará a verdade de tudo que foi dito e provado? Acabada a instrução, todos saem. Fica o juiz a considerar, a olhar o céu vazio, e ver astros apagados. Um estranho e angustiante jogo de sombras. Quando as sentenças traziam o refão, como de sinos dobrando afinados, considerando que...; considerando que, etc. e assim prosseguia até achar o fecho de tantas considerações, a riqueza semântica da voz considerar, que significa literalmente olhar o céu e os astros, deixava a suave impressão de busca de Deus, da inspiração. E era assim que a sentença poderia ser uma consideração, uma inspiração, 
um bater de coração, a expressão egrégia do sentimento, sentimento humano do juiz. E agora? A forma compendiosa da sentença, num complexo de períodos, quase sem parágrafos, como a indicar pressa e ânsia de chegar ao fim, dá bem a ideia do que é um julgamento, que é muito mais a soma impessoal das parcelas postas pelas partes, sem que o juizo tenha meios de lhes examinar a pressuposta exatidão. Por de sobre o papel dos autos estão parcelas e mais parcelas. Ao juiz cabe somá-las. Só é responsável pela correção da soma. E termina o juiz no desalento da irônica fase do compositor popular: ...tudo certo, como dois e dois são cinco. Lá bem no fundo de sua alma, ele sente que a soma só está certa, porque as parcelas estão ali claras, objetivas. Todavia, ele sente que a soma deveria ser outra. Só mesmo quando o processo for obra da Virtude, quando o sentimento da verdade dominar os homens, quando o amor substituir as caducas formas do Direito poderá ser a sentença uma criação do sentimento do juiz.

E fica-se a pensar naquele tormentoso caso da mulher que foi anular seu casamento, em conluio pouco voluntário com o marido. Entrada na realidade, depois de a sentença ter desfeito olarconstituído supostamente sobre o amor, correu a apelar da sentença, que lhe desmanchara todos os sonhos e lha trouxera a desgraça. E apenas ouviu do Tribunal Egrégio essas palavras que queimariam a alma de qualquer um: aquele que vence não tem interesse em recorrer. Obra fria da técnica. Tecnicamente exata a conclusão, mas humanamente infernal e demoníaca. Um pai passara noites e noites a velar o filho agonizante. Levado o corpo a enterrar, semente que jamais germina, voltou o doloroso pai à sua banca de trabalho e fez, então, o recurso que ficara entre notas e esboço sobre a mesa do escritório desertado na loucura da dor de ver morrer-lhe o filho. A máquina infernal da preclusão terminara seu satânico trabalho, impondo silêncio ao litigante vencido. E não recebido o recurso, por estar fora de prazo clamou o enlutado pai pedindo lhe fosse restituído o prazo, e deu sua humana razão. Quem tem um filho a morrer não pode olhar o calendário, a ver se o tempo passou. Só tem que olhar o filho que vai morrendo. E o Tribunal, solene e técnico, só lhe respondeu assim, aos gritos de apelo de humanização e compreensão do seu drama: Só se releva a perda de prazo, quando é advogado quem morre. Obra perfeita da técnica. Mas nunhum estremecimento de emoção, sem uma palpitação de vida sem a mais mínima crispação de sentimento humano. E todos dizem: "mas o formalismo é a garantia das partes”. E calamo-nos. Na sala sombria da audiência entram mulher e marido. Em casa, ficaram os filhos, na inocência do drama que aflinge os pais. Terminado o processo, proferida a sentença, decretado o desquite, filhos distribuídos para um para outro, ou para terceiros, sem consulta prévia ao débil coração das crianças. O juiz contempla sua sentença, e diz de si consigo: tecnicamente a minha sentença é um primor de técnica, de construção jurídica. Mas, aí começa a tragédia de pesssoas inocentes, de 
que a sentença não curou, porque ela teria de considerar eram as provas e obedecer à técnica. E todos dizem: "A técnica é diferente aos fins". E, calamo-nos.

Nos remotos tempos em que o juiz era também o pai, o chefe da Familia, sua sentença poderia ser sentida, obra de seu sentimento, porque tarefa de amor a refletir sobre aqueles a que estava ligado pelos laços da afeição. Áspero e penoso poema deveria ser uma sentença assim, em que seu prolator fosse julgador e pai, porque teria de sofrer para conservar a imparcialidde, essa olorosa flor de todos os pronunciamentos humanos a que se dá o nome de sentença. Mas, pode afirmar-se, sem dúvida possível, que, mesmo julgando pessoas amadas, pode o juiz ser imparcial. Ninguém nega a dolorosa sensação que toma conta do homem posto em tal tormentosa situação. Mas, pode ser-se imparcial mesmo em tais horas. Nos tempos augustos em que o juiz era também sacerdote, a sentença poderia ser obra do sentimento, porque a constância e o poder da Fé faziam do julgador instrumento divino, mediador equidistante entre os homens e a divindade.

Hoje, pobres de nós, operários de uma técnica sem alma e sem piedade, enfeitiçados por ela, dela amorosos até o feiticismo, somos dela levados, e consumamos sua obra, indiferentes aos resultados, preocupados apenas em que eles sejam técnicamente incensuráveis. E a perfeição formal que nos encanta. Somos enamorados da forma, artistas plásticos, trabalhando sobre dores humanas, mas a elas indiferentes. E ainda mantemos sobre nossa mesa a monstruosa imagem da Justiça de olhos vendados.

Aquele Príncipe antigo, exemplar marido, foi tragicamente surpreendido com a morte da mulher amada, sua vida, seu tudo. Mandou erguer-lhe suntuoso mausoléu. A esmerada obra de fino lavor arquitetural, foi sendo feita, enquanto a dor consumia o enlutado marido. Acabada a donosa fábrica, filha de engenhos eleitos da Arte, na hora de lá ser posto o corpo da amada morta, vendo o Príncipe o esplendor da construção, entre orgulhoso e enojado, disse a seus criados: "tirem isso daí", referindose ao corpo da esposa morta. É assim que sempre se tira o homem de dentro da sentença embora para ele é que ela tenha sido especialmente feita. Pagamo-nos da beleza formal da nossa própria construção. Se ela irá servir ao homem para quem foi criada, nisso o construtor não está pensando. E, todavia, somos homens trabalhando para seres humanos.

Somos legitimamente enamorados da Estética, porque nós juízes temos também o nosso tanto artistas. Construir uma sentença é obra de arte, como ser também obra de ciência. Outra, porém, deve ser a nossa Estética. Temos também nossos cânones de Beleza. Mas nossa Beleza é funcional. Reside na bondade do resultado, avaliado em termos de Justiça. Só é bela a sentença que realizar a Justiça, ou dela mais aproximar-se, com um mínimo de dor humana. Somos jardineiros de vidas humanas. Mas, por nossa desgraça, não podemos plantar onde queremos, nem situar a planta nos lugares 
mais próprios ao seu crescimento. Semeamos e plantamos, onde nos manda a técnica, onde nos surgem as formas, os modos, o tempo e a ordem do processo. Em verdade, somos dominados pela irracionalidade da técnica. Toda criação artística, toda beleza criada pela alma transportada do artista, ocorre num momento irracional. Toda beleza nasce das forças incontroláveis da irracionalidade. Deixar passar a ênfase, mas o momento irracional da criação á o mais lúcido de todos os momentos artista. Vem das profundezas da alma e desabrocha como flor de estesia, surpeendendo o próprio criador. Só a sentença do juiz não pode ser o produto de um momento de irracionalidade criadora, porque sua Arte é dominada por outros e estranhos padrões de beleza, que lhe exigem vigilância, que lhe pedem esteja desperto e sobremodo atento, para não falsear os termos do silogismo sobre que constrói sua senteça. É essa lógica de tipo matemático, esse esquema frio de reciocínio dedutivo que não permite ao juiz substituir as premissas por outras que lhe parecem mais exatas, essa é a nossa desgraça de julgadores. O mal não está no metodo dedutivo, porque afinal a sentença sempre se resolve numa dedução. O mal está na quase impossível rejeição da premissa menor, obra humana e passível de mistificação, de falseamento por parte dos tiligantes. A busca do Direito é a longa e maravilhosa viagem do juiz. E ele deveria poder tomá-lo onde o encontrasse, mesmo fora e longe dos Códigos, lá distante, escondido na vida nas obras da milenar experiência humana. Toda nossa tragédia reside em termos de aceitar as parcelas, é só sermos responsáveis pela exatidão da soma. Estou que Epiteto teria dito alguma coisa insensata, quando, em de suas máximas, disse que; $A$ obrigação da natureza não é a de bom pai. Não. A obrigação que vem da natureza é de ser pai; mas a que vem da regra moral da vida é a de ser bom pai. Epiteto sofismou onde não deveria. Mudemos apenas pai para juiz. A obrigação funcional do juiz é ser juiz e julgar segundo a prova dos autos. Mas, a obrigação humana do juiz é julgar de modo que sua justiça sirva àqueles para quem a faz. A sentença tem de ser sentida, tem de passar antes pela alma sensível do homem que julgo para poder alcançar o homem julgado. É o mais longe caminho o que vai de alma a alma. Pode podém, tornar-se o melhor e mais curto, se se achar o caminho certo pelo qual as almas se comunicam. E a sentença tem de ser comunicada de alma a alma, maciamente, suavemente, sem ferir, sem sangrar, Toda sentença deve ser um canto, um suave canto, a cantar a grandeza imensurável de Justiça. Um canto mavioso de vitória. Vitória sobre a técnica. Obra de amor a pacificar as almas em conflito. A primeira e mais importante intenção da sentença deve ser a de convencer, para que não aja vencido. A maior vitória não é a de vencer. A maior vitória não é do vencedor, é a do convencido. Onde houver a convicção, não há derrota; Meu adversário ganhou bem; não me sinto vencido, porque sua vitória foi correta. A sentença convenceu-me. Poucas vezes em nossa vida teremos 
oportunidade de ouvirmos essas consoladoras palavras a propósito de nossas sentenças. Falta aos homens, na maioria das vezes, grandeza de alma para ouvirem a palavras finais duma sentença. Sabe Deus como nos treme a mão ao lançarmos no papel o julgo com que pomos remate ao nosso laborioso trabalho, no silêncio vazio das noites em que só nós velamos na busca demorada e esquiva da conclusão da sentença que temos o dever de proferir. Aquele juiz que, antes de chegar à sua sala de julgamentos, passava pelo comércio e adquiria no câmbio negro, o leite para seu filho enfermo. E tinha de condenar, em seguida, o comerciante que vendia no câmbio negro. Trágica, mas verdadeira história. Terrível como tudo que é só humano, apenas humano, puramente humano. Barro impuro que nem a pureza divina das lágrimas impede que se converta em lama. E fica a pergunta que nos envolve e mortifica: o juiz, pois é ele quem faz a sentença. Aqui, a lógica nos conduz a erro. A sentença é maior que o juiz. Passamos. Nossa sentença permanece para o bem, ou para o mal, embora, queiramos que ela seja para o bem (Rosa, 1975b, p. 220-227).

Eliézer Rosa foi contemporâneo, entre outros processualistas, citamos apenas alguns, de Luiz de Macedo Soares Machado Guimarães, Alfredo Buzaid, Luiz Eulálio de Bueno Vidigal, todos discípulos de Enrico Tullio Liebman, que, junto com Carnelutti e Chiovenda, influenciaram sobremaneira o pensamento jurídico nacional praticamente no nascimento de uma doutrina processual civil em nosso País, aliás, verdadeiros Mestres a quem foi reservado um destino providencial: o de chefes de Escola. Chiovenda é, sem dúvida alguma, fondatore della nuova scuola processuale italiana (Carnelutti, 1937, p. 297). Liebman é o fundador da ciência processual brasileira, e a sua presença entre nós significou a alvorada do direito processual civil como sistema científico.

Eliézer Rosa escreveu admiravelmente, com a lucidez da criatura humana que compreende a outra, sem a vaidade e a superioridade natural de quem ocupa um cargo relevante, sabendo que seu exercício só se justificaria se estivesse próximo da criatura humana para quem o direito e a justiça deve estar voltado.

Eliézer escreveu, dirigindo-se aos jovens que viriam substituir os processualistas civis, páginas que valem por uma vida, uma filosofia, uma mensagem inapagável, uma luz, um rumo e um farol a iluminar tanta escuridão, que por vezes invade o território do processo, quando a obra de coisificação do homem persiste em erigir estruturas voltadas ao formalismo exacerbado.

Disse o mestre incomparável:

Ética e Estética no processo civil - A corrente ética corresponde ao romantismo processual; a corrente estética pretence ao classicismo processual. Todos que têm leituras 
em Teoria da Literatura sabem o que foi o classicismo e o que foi o romantismo. São ambos tratados como correntes estéticas literárias. Aqui chamaremos ao romantismo corrente ética, e ao classicismo corrente estética, para os fins deste despretencioso estudo processual, ou, talvez, de filosofia processual. Não é um ensaio. Para isso faltalhe tudo São notas que, em outras mãos, poderiam servir, para, com elas, fazer, ao lado de outras meditações, um ensaio sobre o tema, altamente sugestivo. Os dísticos que encimam este escrito dão bem a medida das divergências de pensamento entre homens de prol nas artes e nas ciências, quando acertam de meditar sobre o assunto. É o processo judicial uma Arte, ou uma Ciência? Eis o problema. Se for simplesmente arte, os fins pouco importam, por isso mesmo que, sendo arte, é técnica. Assim, os fins pouco importam. O bom é o bem feito. Estou que o processo judicial participa da natureza das coisas artísticas e das coisas cientifícas. Ele tem sua ética e sua estética próprias, peculiares. Ele visa o bom, como também o bem feito, mas não pode o processualista afirmar que o bom em Processo é o bem feito. Se fosse apenas arte, sua técnica exigiria o bem feito, fosse ou não bom. Sua estética exigiria sempre o perfeito, o mais belo, porque aí o belo seria o esplendor do verdadeiro, na frase de Ruskin. Mas, sendo ciência, tem sua técnica, que extingue o bom, por si mesmo, ou que alcance o bom pelos melhores caminhos. Os resultados, os fins, importam imensamente, como também os meios. Aqui os meios comprometem o fim. E se o fim não for bom, os meios não servem, ainda que sejam os mais perfeitos em si mesmos. A mais perfeita e admirável síntese a que chegou o torturado pensamento filosódico processual, ao longo do seu caminho dialético, foi esta: $\mathrm{O}$ processo judicial tem sua gramática e seus materiais próprios, tem a sua ética peculiar. Sua ética é sua estética, porque sua estética é funcional, como sentenciou Llewellyn. A beleza funcional, conceito que enfeixa as duas aspirações constrastantes dentro da vida do Processo. A mais bela síntese apaziguadora do pensamento já quase desfeito pelo cansaço da caminhada. A estética do Processo é a sua ética, porque a beleza buscada é a beleza funcional. Só é belo o que for bom para o Homem. Eis a suprema verdade dentro do Processo. O processo judicial não é um simples fazer. É um agir, ao lado de um fazer. Não nego, e ninguém negaria que o processo vive muito do fazer, porque ele será sempre composto de condutas humanas, disciplinadas por uma concepção formal e técnica das atividades desenvolvidas em sua realização. O Processo Judicial pertencerá sempre ao mundo das formas, mas formas que têm sua própria substantividade. Ninguém imaginaria retirar o Processo desse seu mundo peculiar. $\mathrm{O}$ 
mal contra quem estou, aqui, pretendendo advertir os novos é o da preocupação estetizante, é o do construcionismo, o da técnica pela técnica. O mal do Processo Judicial moderno reside no fato de ele preocupar-se com suas estruturas, e não interessar-se tanto por sua função. Não poderão os novos de perder de vista esta significativa verdade já revelada pela Ciência processual, a saber, que o Processo é instrumental, é meio, e não fim, em si mesmo. Toda vez que se pensar em Processo, como fim de si mesmo, se estará prestando homenagem às correntes estetizantes do Processo, em detrimento das correntes éticas, que lhe insuflam vida e sentido humano. O mais antigo exemplo desse pensamento estético do Processo pode ir buscar-se nas legis actiones do velho processo romano. Gaio refere aquilo do litigante que pronunciou a palavra vida em lugar de dizer árvore, tendo, por isso, perdido a demanda, consumindo sua ação. Todo Processo romano, dentro da ordi judiciorum privatorum, foi duramente estetizante. Vejase o que eram as formulae, a flor de uma rude estética processual, perfumada, sem dúvida, pelas firmezas duma exemplar técnica jurídica. Mas eram elas o pleno domínio da estética. Foi um período intrinsecamente estetizante. Gabriel Tarde, em seu formoso livro intitulado Les Transformations $d u$ Droit, no capítulo versante sobre procédure, na nota de páginas 36, da edição de 1893, dá o a que ele chamou Un exemple entre mille. Convém saber: um litigante acionou o vizinho, pedindo perdas e danos por um fato qualquer. $\mathrm{O}$ autor ganhou a demanda com a condenação do réu ao pagamento de uma indenização de setecentos francos. Ocorreu que, redação de sentença, o Juiz omitiu que as testemunhas prestaram juramento, embora elas o houvessem prestado. Todos sabiam disso. Mas, faltou a menção do fato na redação do relatório da sentença condenatória. O réu, em recurso de cassação, alegou a nulidade do julgamento, em vista daquela omissão, embora a omissão do juramento da testemunhas só tivesse ocorrido no relatório da sentença, pois, em verdade, elas juraram. Obteve a anulação do processo, diz o sociólogo que conta o fato. Vencido agora o autor da ação, sois, então condenado a reembolsar ao réu originário a quantia de 1.800 francos. Ajunta o mesmo Tarde que o autor originário da ação ficou indignado e espantado com o resultado, mas de nada lhe valeu isso, porque seus bens foram penhorados e adjudicados a preço vil ao vencedor da última instância, alcançando o suficiente para cobrir também as despesas do processo. E termina o mesmo Tarde: Voilà un homme ruiné pour avoir ganhé son procès; je pourrais mème dire pour l'avoir ganhé deux fois, car après as ruiné, le nouveau tribunal saisi de l'affaire, a jugé comme le premier." Eis o frio da estética, do 
pensamento estetizante, dentro do Processo Judicial. Essa é a obra má da técnica sem o toque humano, sem a visão do homem que está envolvido nas formas de um processo. A máxima de tal escola de pensamento será esta: fazer belamente, de modo tecnicamente perfeito, ainda que o homem pereça. Era assim que procedia o médico Tomès, partidário de Artêmio, para quem um morto era apenas um morto, a observância, porém, das formalidades do sistema era importante para toda classe médica, sucedesse o que sucedesse. A concepção ética do Processo, porém, valoriza o problema humano, põe o Homem como o centro do Processo, e estima as condutas processuais por critérios superiores de moral. $\mathrm{O}$ que desejam as correntes éticas do Processo é que, em lugar do formalismo à outrance, que compromete os fins essenciais do Processo, se construa um filosofia humanista, se adote uma ideia antropocêntrica do Processo, deixando de lado essa filosofia arquitetural, construcionista, que perdeu de vista o Homem para quem o Processo deve ser feito. $\mathrm{O}$ humanismo processual quer trazer o Homem para o centro das atenções do Juiz. Para esta filosofia processual humanista, as condutas processuais estão situadas na ordem do agir. A máxima desta concepção é fazer o bem e não só fazer bem feito. Aqui, nem sempre o bem feito é o melhor. O mais alto representante desta corrente de pensamento estará na figura histórica e milenar de Papiano que teve morte por negar-se a justificar o fratricídio por Caracala. Como Caracala, pensava totalmente Frederico II, mas, para um e outro, haverá sempre Papianos, que preferirão a morte. Nas múltiplas circunstâncias da vida, os homens do Direito são postos à prova, em suas convicções éticas a serviço de sua profissão (Rosa, 1986, p. 132-135).

Eliézer nos legou páginas de incomensurável beleza e adequação a todos que vivemos no Foro, ao escrever sobre a grandeza do direito, auxiliando-nos a compreender o que por vezes nos deixa perplexos, constrangidos e acabrunhados, quando nos deparamos com a contradição da função do direito e a estrutura que se proporciona a sua realização.

A grandeza do direito - A grandeza do direito é a sua função. Sua miséria é a sua estrutura. O legislador, em suas codificações, pretende ser onisciente e deseja que sua obra seja eterna, esquecido, talvez, de que alguma hora surja a inevitável falta de sincronização entre os meios e os fins, emtre os problemas e as soluções. Daí muitas vezes, ter o julgador de passar pelo Código, ir além dele, para alcançar um julgamento em termos de justiça. E então que se ouve aquela terrificante afirmação para os estetas do direito, a saber, fazer justiça apesar da lei, apesar do Código. Entre a Lei, o Código e o Direito está posta a mais dura opção para o esteta, mas uma 
fácil escolha para o ético, porque este sempre ficará com o Direito, despreocupado da Lei e dos Códigos, que ano esgotam, em sua pretendida onisciência, a totalidade do Direito. O triunfo que está reservado ao jurista é o de realizar a beleza plástica da função, através da instrumentalidade ads estruturas. O jurista que não souber ou não puder docilizar e domesticar as estruturas, e, até por vezes menos violentá-las para alcançar a realização superior da função terá falhado em sua missão. O jurista que não tiver sensibilidade sufuciente para ouvir, cada dia, o fragor de estruturas legais, quebrando-se; que não tiver a atenção voltada para os quadros legais a se partirem, alargando, ampliando, os velhos emolduramentos, está fora e longe deste mundo, distanciando, mal a seu grado, da realidade em vigília. A vida muda e, pois, o Direito tem de mudar com ela.

A função do Direito é realizar os interesses humanos que entram na categoria dos valores jurídicos. É aqui que entra a estética funcional, que não é a beleza formal da expressão literal dos Códigos; que não é a sua gramática, nem seu estilo literário, nem sua lição de purismo vernacular. Não é aquela beleza procurada por Rui, penteando com os artefatos do purismo linguístico e literário a redação do nosso Código Civil, nem é aquela beleza buscada por Stendhal nos versículos do Código Civil de Napoleão, na ânsia da simplicidade expressiva que o torturava esteticamente. É outra beleza, a beleza funcional que reside na bondade das soluções dos problemas humanos. Beleza mais rara, mais difícil, menos achadiça. É a beleza funcional que faz o jurista orientar-se pela ética das soluções, harmonizando os problemas com as soluções, sem angustiar o Homem, sem tornar-lhe mais penosa e constrangedora a vida e suas malignidades. O mínimo de angústia e o máximo de segurança, eis a lição que desce da ética para a mente e a obra do jurista. Afinal, o Direito foi feito para o Homem (Rosa, 1986, p. 46-47).

O canto da liberdade do homem não está apenas nas Constituições. Está nos Códigos de Processo. E neste, a carta das liberdades está escrita no capítulo dos recursos. É a segunda instância a genial criação, a suavíssima canção da liberdade. O Estado nunca se dá por satisfeito com as decisões de um só Juiz. É certo que uma presunção de legalidade cobre os atos dos Poderes do Estado. Quem quiser impugnar os atos estatais tem à sua disposição os recursos. E eles deverão ser amplos e múltiplos. É verdade que os juízes do nosso tempo são consumados técnicos, e escolhidos mediante rigoroso sistema de provas intelectuais. Mas, isso não basta ao litigante que sucumbe. Ele quer a liberdade de procurar uma decisão que traga a justiça que lhe parece ser a justiça do seu caso. Afinal, a justiça é buscada pelo homem que paga as despesas dessa procura. As leis processuais deveriam ser obra não apenas de juristas, mas de filósofos. Um processo sem filosofia é uma demoníaca máquina de fabricar angústia e desesperos humanos (Rosa, 1975a, p. 21).

Encerro este artigo com um pedido de escusas aos seus eventuais leitores, pois, consciente que escrevi com 
as minhas limitações sobre alguém que a vida demonstrou ser um espírito avançado e superior no seu tempo, rasgando, na alma e nos corações dos homens dedicados à causa da justiça, caminhos mais suaves e melhores, na aventura humana em que todos nós somos irmãos, e que Eliézer, de forma extraordinariamente bela e humanizada, apontou a direção no processo.

\section{REFERÊNCIAS}

CARNELUTTI, Francesco [18791965]. Appunti sul procedimento di cognizione secondo Il Progetto Solmi. Rivista di Diritto Processuale Civile, Padova, v. 14, parte 1, p. 269-281, 1937.

RECASÉNS SICHES, Luís [19031977]. Nueva filosofía de la interpretación del derecho. México-Buenos Aires: Fondo de Cultura Económica, 1956. 308 p. ROSA, Eliézer [1909-2002]. Capítulos de história do direito processual civil brasileiro. Rio de Janeiro: Rio, 1975a. 3 v. (Cadernos de processo civil, 3). ROSA, Eliézer [1909-2002]. Dicionário de processo civil. 2. ed. São Paulo: José Bushatsky, 1973. 427 p.

ROSA, Eliézer [1909-2002]. Dicionário de processo penal. Rio de Janeiro: Rio, 1975b. 267 p.

ROSA, Eliézer [1909-2002]. Novo dicionário de processo civil. Rio de Janeiro: Livraria Freitas Bastos, 1986. 322 p. 